\title{
Front Matter: Volume 11077
}

, "Front Matter: Volume 11077," Proc. SPIE 11077, Opto-Acoustic Methods and Applications in Biophotonics IV, 1107701 (30 September 2019); doi: 10.1117/12.2542337

SPIE. Event: European Conferences on Biomedical Optics, 2019, Munich, Germany 


\title{
PROGRESS IN BIOMEDICAL OPTICS AND IMAGING
}

\section{Opto-Acoustic Methods and Applications in Biophotonics IV}

\author{
Vasilis Ntziachristos \\ Roger Zemp \\ Editors
}

\section{4-25 June 2019 \\ Munich, Germany}

Sponsored by

The Optical Society (United States)

SPIE

Published by

SPIE 
The papers in this volume were part of the technical conference cited on the cover and title page. Papers were selected and subject to review by the editors and conference program committee. Some conference presentations may not be available for publication. Additional papers and presentation recordings may be available online in the SPIE Digital Library at SPIEDigitalLibrary.org.

The papers reflect the work and thoughts of the authors and are published herein as submitted. The publisher is not responsible for the validity of the information or for any outcomes resulting from reliance thereon.

Please use the following format to cite material from these proceedings:

Author(s), "Title of Paper," in Opto-Acoustic Methods and Applications in Biophotonics IV, edited by Vasilis Ntziachristos, Roger Zemp, Proceedings of SPIE-OSA Vol. 11077 (SPIE, Bellingham, WA, 2019) Seven-digit Article CID Number.

ISSN: 1605-7422

ISSN: 2410-9045 (electronic)

ISBN: 9781510628472

ISBN: 9781510628489 (electronic)

Copublished by

SPIE

P.O. Box 10, Bellingham, Washington 98227-0010 USA

Telephone +1 3606763290 (Pacific Time) · Fax +1 3606471445

SPIE.org

and

\section{The Optical Society}

2010 Massachusetts Ave., N.W., Washington, D.C., 20036 USA

Telephone 1 202/223-8130 (Eastern Time) · Fax 1 202/223-1096

http://www.osa.org

Copyright ( 2019, Society of Photo-Optical Instrumentation Engineers and The Optical Society.

Copying of material in this book for internal or personal use, or for the internal or personal use of specific clients, beyond the fair use provisions granted by the U.S. Copyright Law is authorized by SPIE subject to payment of copying fees. The Transactional Reporting Service base fee for this volume is $\$ 21.00$ per article (or portion thereof), which should be paid directly to the Copyright Clearance Center (CCC), 222 Rosewood Drive, Danvers, MA 01923. Payment may also be made electronically through CCC Online at copyright.com. Other copying for republication, resale, advertising or promotion, or any form of systematic or multiple reproduction of any material in this book is prohibited except with permission in writing from the publisher. The CCC fee code is 1605$7422 / 19 / \$ 21.00$.

Printed in the United States of America by Curran Associates, Inc., under license from SPIE.

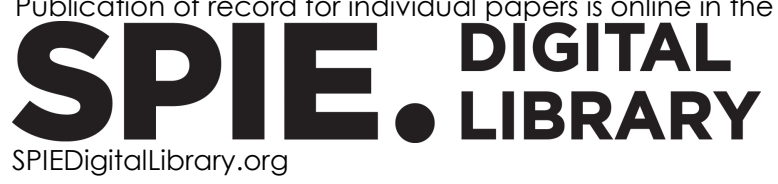

Publication of record for individual papers is online in the SPIE Digital Library.

Paper Numbering: Proceedings of SPIE follow an e-First publication model. A unique citation identifier (CID) number is assigned to each article at the time of publication. Utilization of CIDs allows articles to be fully citable as soon as they are published online, and connects the same identifier to all online and print versions of the publication. SPIE uses a seven-digit CID article numbering system structured as follows:

- The first five digits correspond to the SPIE volume number.

- The last two digits indicate publication order within the volume using a Base 36 numbering system employing both numerals and letters. These two-number sets start with 00, 01, 02, 03, 04, 05, 06, 07, 08, 09, 0A, OB ... 0Z, followed by 10-1Z, 20-2Z, etc. The CID Number appears on each page of the manuscript. 


\section{Contents}

$\begin{array}{ll}\text { vii } & \text { Authors } \\ \text { ix } & \text { Conference Committee }\end{array}$

\section{CLINICAL APPLICATIONS II}

1107705 Optoacoustic guidance for stem cell therapy [1 1077-4]

1107707 High-frequency photoacoustic and ultrasound imaging of systemic sclerosis patients [1 1077-6]

1107708 Tumor ablation and volumetric optoacoustic monitoring with a short-pulsed laser source [11077-7]

1107709 In-situ temperature monitoring with photoacoustics during photothermal therapy and perspectives for glioblastoma treatment monitoring [1 1077-8]

\section{ALGORITHMS AND QUANTITATIVE IMAGING}

11077 OB Analysis of different approaches for blood oxygenation determination from multispectral optoacoustic measurements [11077-10]

11077 OD Photoacoustic computed tomography for joint reconstruction of initial pressure and sound speed in vivo using a feature coupling method [1 1077-12]

$11077 \mathrm{OE} \quad$ Use of angular distribution of differential photoacoustic cross-section data for estimating source size [11077-13]

NOVEL DETECTORS AND SYSTEMS I

$11077 \mathrm{OH} \quad$ Probing the optical readout characteristics of Fabry-Pérot ultrasound sensors through realistic modelling [11077-16]

11077 Ol Optical phase shifted pulse interferometry for parallel multi-channel ultrasound detection [11077-17]

11077 OK Multimodal imaging through a multimode fiber [1 1077-19] 
NOVEL DETECTORS AND SYSTEMS II

$11077 \mathrm{OL} \quad$ Annular illumination photoacoustic probe for needle guidance in medical interventions [11077-20]

11077 ON Developments on using supercontinuum sources for high resolution multi-imaging instruments for biomedical applications [11077-22]

11077 OP Out-of-plane artifact removal in photoacoustic imaging using transducer array displacement [11077-24]

$110770 Q \quad$ Photoacoustic tomography setup using LED illumination [1 1077-25]

\section{MICROSCOPY}

11077 OX Generation and monitoring of cavitation with an optical resolution photoacoustic microscope [11077-33]

11077 OY Dual-wavelength nanosecond pulsed-laser using stimulated Raman scattering for fast functional photoacoustic microscopy [11077-34]

\section{POSTER SESSION}

1107711 Optoacoustic angiography of experimental tumors [11077-26]

1107713 A robust modified delay-and-sum algorithm for photoacoustic tomography imaging with apodized sensors [11077-38]

1107714 Pulse interferometry with a free-space Fabry-Pérot for shot-noise-limited detection of ultrasound [11077-39]

1107715 Photoacoustic assisted device guidance and thermal lesion imaging for radiofrequency ablation [1 1077-40]

1107716 Laser-induced ultrasound transmitters for 3D photoacoustic and ultrasound tomography [11077-41]

11077 1B Fundamental study for identification and elimination of reflection artifacts with photoacoustic spectrum [1 1077-47]

11077 1C Combined photoacoustic and fluorescence label-free microscopy for the ex-vivo investigation of ocular tissues [11077-48]

$11077 \mathrm{IE} \quad$ Acoustic resolution photoacoustic microscopy with large area optical ultrasound detection [11077-50]

11077 1G Large area all-optical ultrasound imaging using robotic control [1 1077-52] 
$11077 \mathrm{lH} \quad$ Non-invasive in-vivo sensing of metabolites with a novel optoacoustic spectroscope in the SWIR [1 1077-53]

$1107711 \quad$ Model for the description of remote photoacoustic sensing using speckle-analysis [1 1077-54]

11077 1 J Evaluation of arthritis with model rats using photoacoustic imaging system [1 1077-55]

$11077 \mathrm{lK} \quad$ Multiphysics simulation approach for photo-acoustics temperature monitoring in rodent's head during photothermal therapy [11077-56]

$110771 \mathrm{~L} \quad$ Acoustic differentiation of dental soft and hard tissues using remote speckle-analysis during Er:YAG ablation [1 1077-57]

11077 1M Intraplaque haemorrhage detection using single-wavelength PAI and singular value decomposition in the carotid artery [11077-58]

11077 IP Probing intervertebral discs with photoacoustics [1 1077-61]

11077 1Q Remote speckle-sensing for improved differentiation between different types of tissues [11077-62]

11077 IR Camera-based photoacoustic remote sensing microscopy [11077-63] 
Proc. of SPIE-OSA Vol. 11077 1107701-6

Downloaded From: https://www.spiedigitallibrary.org/conference-proceedings-of-spie on 25 Apr 2023 Terms of Use: https://www.spiedigitallibrary.org/terms-of-use 


\section{Authors}

Numbers in the index correspond to the last two digits of the seven-digit citation identifier (CID) article numbering system used in Proceedings of SPIE. The first five digits reflect the volume number. Base 36 numbering is employed for the last two digits and indicates the order of articles within the volume. Numbers start with 00, 01, 02, 03, 04, 05, 06, 07, 08, 09, OA, OB...0Z, followed by 10-1Z, 20-2Z, etc.

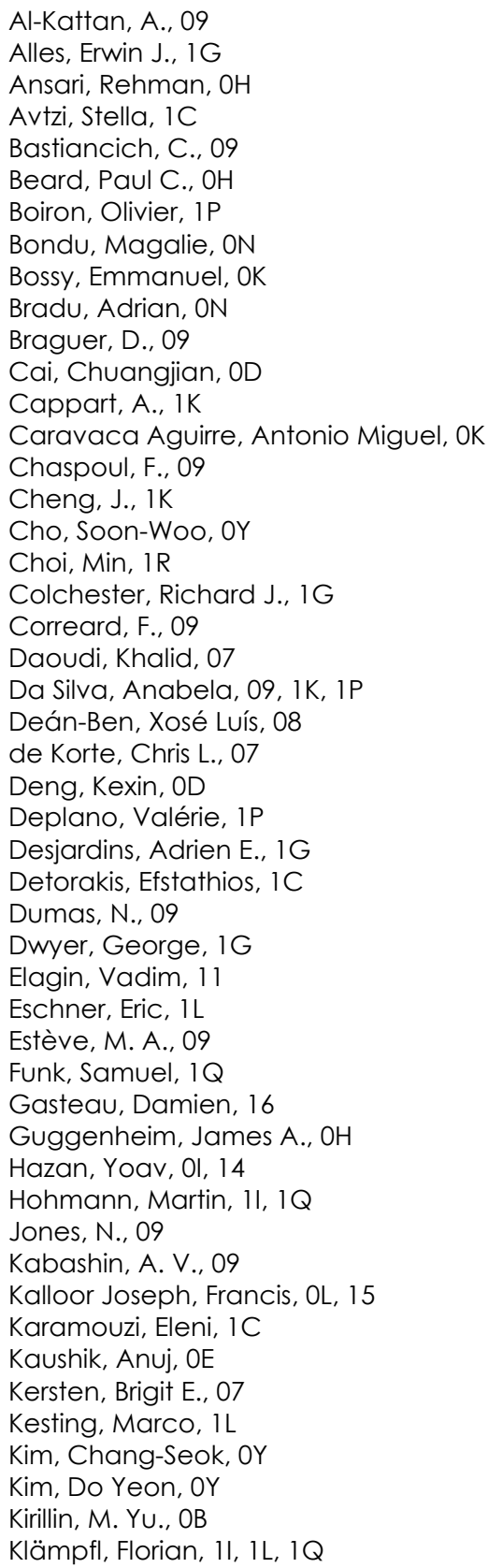

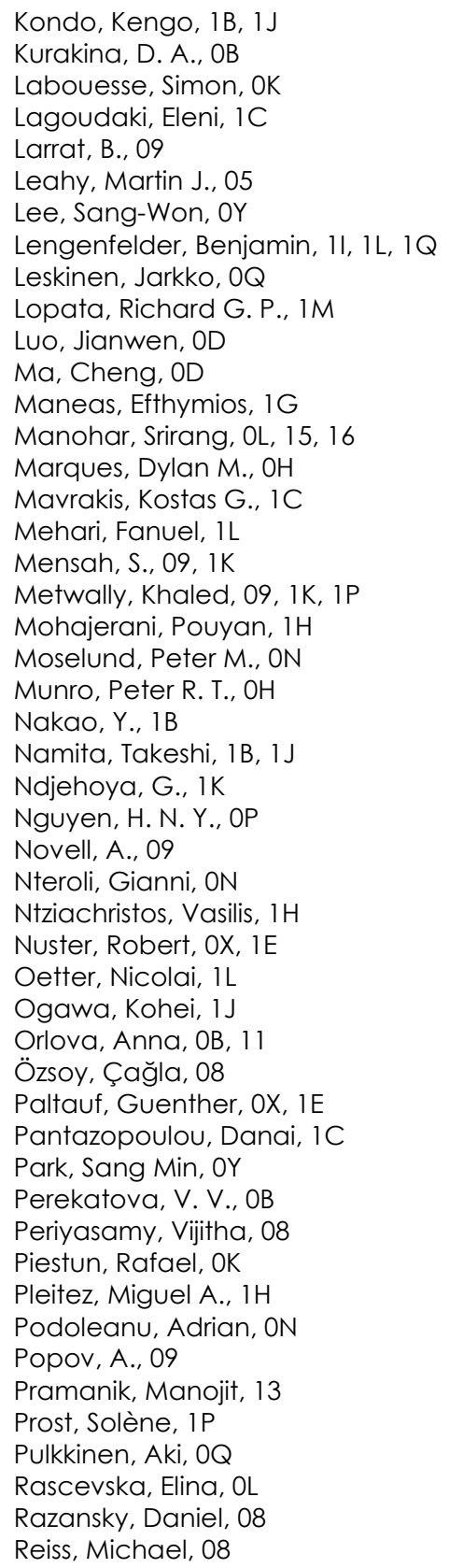


Rosenthal, Amir, 0l, 14

Rupitsch, Stefan J., 11

Rupp, Patrick, $1 \mathrm{E}$

Rutten, Marcel C. M., 1M

Saha, Ratan K., OE, 13

Schmidt, Michael, 1I, 1L, 1Q

Schwarzkopf, Karen, 1L

Seyedebrahimi, M. Mehdi, $1 \mathrm{H}$

Shiina, Tsuyoshi, 1B, 1J

Singh, Sakshi, OK

Sirotkina, Marina, 11

Smolina, Ekaterina, 11

Sonker, Deepak, OE

Späth, Moritz, 1Q

Steenbergen, W., OP

Stelzle, Florian, 1L, 1Q

Stoyanov, Danail, 1G

Subochev, Pavel, OB, 11

Tarvainen, Tanja, $0 \mathrm{Q}$

Thompson, David, 16

Tick, Jenni, OQ

Tselikov, G., 09

Tserevelakis, George J., 1C

Tsilimbaris, Miltiadis K., 1C

Turchin, llya $\mathrm{V}_{\text {., OB }, 11}$

van de Vosse, Frans N., $1 \mathrm{M}$

van Hees, Roy P. M., $1 M$

Volodarsky, Oleg, 14

Vonk, Madelon, 07

Wang, Xuanhao, OD

Warbal, Pankaj, 13

Weiß, Manuel, 11

Wu, Min, $1 \mathrm{M}$

Yamakawa, Makoto, 1B, IJ

Zacharakis, Giannis, 1C

Zalevsky, Zeev, 11, 1L, 1Q

Zam, Azhar, 11

Zemp, Roger J., $1 \mathrm{R}$

Zhang, Edward Z., $\mathrm{OH}$ 


\title{
Conference Committee
}

\author{
General Chairs
}

Brett E. Bouma, Wellman Center for Photomedicine (United States)

Paola Taroni, Politecnico di Milano (Italy)

Programme Chairs

Ronald Sroka, Laser-Forschungslabor (Germany)

I. Alex Vitkin, University of Toronto (Canada)

Conference Chairs

Vasilis Nłziachristos, Helmholtz Zentrum München GmbH (Germany) and Technische Universität München (Germany)

Roger Zemp, University of Alberta (Canada)

Conference Programme Committee

Emmanuel Bossy, Laboratoire Interdisciplinaire de Physique (France)

Ben T. Cox, University College London (United Kingdom)

Stanislav Y. Emelianov, Georgia Tech Research Institute (United States)

Jan Grimm, Memorial Sloan-Kettering Cancer Center (United States) Fabian Kiessling, Uniklinik RWTH Aachen (Germany)

Chulhong Kim, Pohang University of Science and Technology

(Korea, Republic of)

Michael C. Kolios, Ryerson University (Canada)

Srirang Manohar, Universiteit Twente (Netherlands)

Alexander A. Oraevsky, TomoWave Labs, Inc. (United States)

Guenther Paltauf, Karl-Franzens-Universität Graz (Austria)

Amir Rosenthal, Technion-Israel Institute of Technology (Israel)

Gijs van Soest, Erasmus MC (Netherlands)

Lihong V. Wang, Caltech (United States)

Vladimir P. Zharov, University of Arkansas for Medical Sciences (United States)

\section{Session Chairs}

1 Clinical Applications I

Vasilis Ntziachristos, Helmholtz Zentrum München GmbH (Germany) and Technische Universität München (Germany)

Roger Zemp, University of Alberta (Canada) 
3 Algorithms and Quantitative Imaging

Ben T. Cox, University College London (United Kingdom)

Antonio Miguel Caravaca Aguirre, Laboratoire Interdisciplinaire de Physique (France)

4 Novel Detectors and Systems I

Amir Rosenthal, Technion-Israel Institute of Technology (Israel)

5 Novel Detectors and Systems II

Robert Nuster, Karl-Franzens-Universität Graz (Austria)

Srirang Manohar, Universiteit Twente (Netherlands)

6 Advances in Optoacoustic Imaging

Daniel Razansky, ETH Zurich (Switzerland)

Jan Laufer, Martin-Luther-Universität Halle-Wittenberg (Germany)

ECBO Plenary Session

I. Alex Vitkin, University Health Network (Canada)

Ronald Sroka, Laser-Forschungslabor (Germany)

7 Microscopy

Xosé Luis Deán-Ben, Helmholtz Zentrum München GmbH (Germany) 